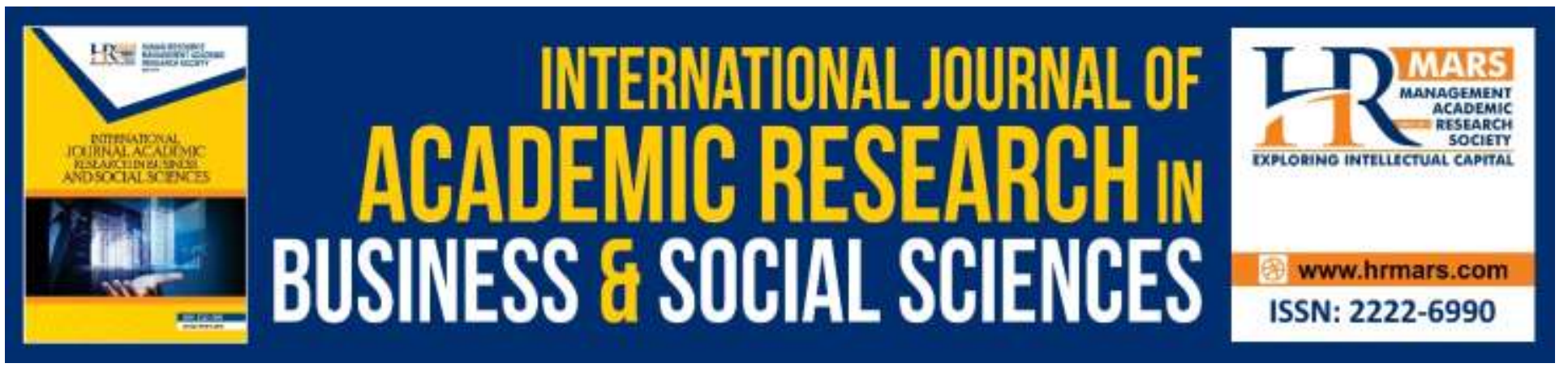

\title{
Analyzing the Impact of Multiple Intelligence of Administrative Mind on the Intellectual Capital: An Applied Study on the Pharmaceutical Industry Companies in Jordan
}

Ghassan Issa Alomari, Imad Hassouneh, Neama Abbas Al-Khafagi

To Link this Article: http://dx.doi.org/10.6007/IJARBSS/v9-i7/6136

DOI: 10.6007/IJARBSS/v9-7/6136

Received: 11 May 2019, Revised: 11 June 2019, Accepted: 02 July 2019

Published Online: 30 July 2019

In-Text Citation: (Alomari, Hassouneh, \& Al-Khafagi, 2019)

To Cite this Article: Alomari, G. I., Hassouneh, I., \& Al-Khafagi, N. A. (2019). Analyzing the Impact of Multiple Intelligence of dministrative Mind on the Intellectual Capital: An Applied Study on the Pharmaceutical Industry Companies in Jordan. International Journal of Academic Research in Business and Social Sciences, 9(7), 437-450.

Copyright: (C) 2019 The Author(s)

Published by Human Resource Management Academic Research Society (www.hrmars.com) This article is published under the Creative Commons Attribution (CC BY 4.0) license. Anyone may reproduce, distribute, translate and create derivative works of this article (for both commercial and non-commercial purposes), subject to full attribution to the original publication and authors. The full terms of this license may be seen at: $\underline{\text { http://creativecommons.org/licences/by/4.0/legalcode }}$

Vol. 9, No. 7, 2019, Pg. 437 - 450

http://hrmars.com/index.php/pages/detail/IJARBSS

Full Terms \& Conditions of access and use can be found at http://hrmars.com/index.php/pages/detail/publication-ethics 


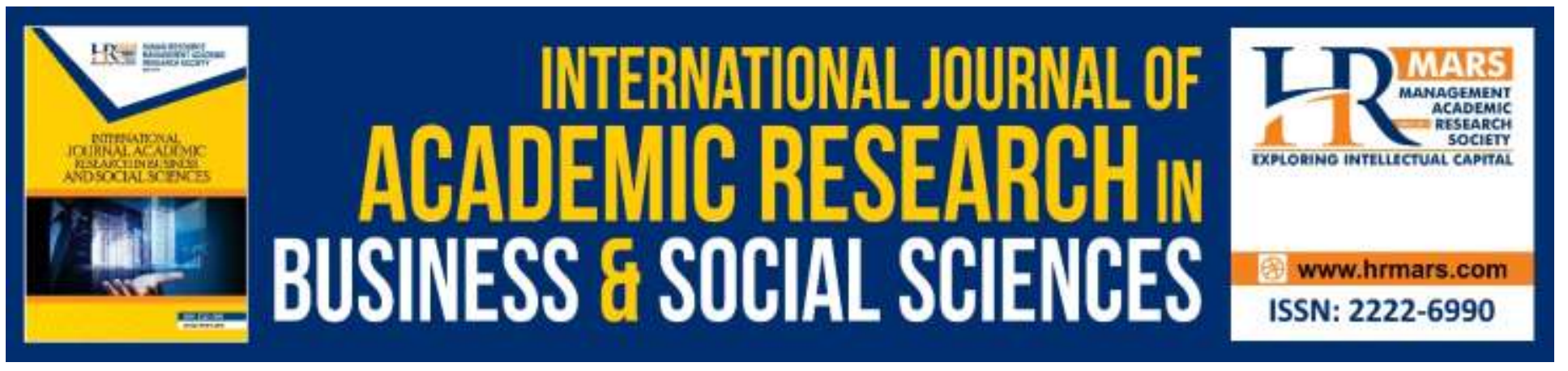

\title{
Analyzing the Impact of Multiple Intelligence of Administrative Mind on the Intellectual Capital: An Applied Study on the Pharmaceutical Industry Companies in Jordan
}

\author{
Dr. Ghassan Issa Alomari, Dr. Imad Hassouneh, Prof. Neama \\ Abbas Al-Khafagi \\ Amman Arab University, Petra University, Isra Private University \\ Email: ghassanomari@aau.edu.jo,Ihassouneh@uop.edu.jo,neamaabass@yahoo.com
}

\begin{abstract}
The task of this research focuses on analyzing the impact of multiple intelligence of administrative mind in its elements (business, political, spiritual and emotional) on the components of intellectual capital (human, operation, innovation and customer). This supposition was tested in the pharmaceutical industry companies in Jordan on a sample of (32) managers.

The results of the descriptive statistical analysis indicated that there are high levels of multiple intelligence of the administrative mind arranged sequentially (businesses, emotional, political and spiritual). There are also high levels of intellectual capital of its two types (customer, processes) and moderate levels of intellectual capital of its other two types (innovation, human). The multi linear regression analysis indicated that there is an impact of the multiple intelligence of administrative mind of its two types (business, spiritual) on the intellectual capital in the pharmaceutical industry companies in Jordan at $(\alpha \leq 0.05)$. There is no impact of the multiple intelligence of the administrative mind of its two types (emotional, political) on the intellectual capital in the pharmaceutical industry companies in Jordan at $(\alpha \leq 0.05)$.

The study recommends enhancing the utilization of the multiple intelligence of the administrative mind and the intellectual capital in its two types (customer and operation). It's necessity to give greater attention to the capital of pharmaceutical industry companies as well as in the innovation capital which includes further support to the innovation incubators and patents that distinguish the companies' products and realizes an added value in the industry that goes through more competition at the local, regional and international level.
\end{abstract}

Keywords: Multiple Intelligence, Intellectual Capital, Pharmaceutical Industry Companies. 


\section{Research Problem}

The topic of multiple intelligence evoked substantial interest among scholars and researchers in psychology in general, and in organizational and industrial psychology in particular. Attempts to study and analyze types of intelligence have focused on multiple dimensions of the administrative mind as being one of the sources to better-know that mind. There is still considerable disagreement about the number and types of these dimensions. This study focused on the business, emotional, spiritual and political intelligences as being critical fields that deserve research and analysis in the contemporary organizations. Intellectual capital has been subjected to measurement and evaluation by specialists in organizational behavior, knowledge economy and human resources management, trying to diagnose its fields of study at local and international scale. Hence came the interest of this study in the human capital, process capital, innovation capital and customer capital according to a concept controlled by diversity and integration. On the other hand, some studies, including the study of Migrash (2016), recommended further studies on multiple intelligence. The study of Jawad and Sharbati (2010) also recommended conducting more studies on pharmaceutical companies in Jordan and studying their intellectual capital. Theoretical and practical investigation reveals that few studies have examined the impact of multi intelligence of the administrative mind on the intellectual capital collectively. This knowledge gap has stimulated the adoption of the research problem as a fundamental issue whereby it could be an indicator to determine this key question:

What is the impact of multiple intelligence of the administrative mind (business, political, spiritual and emotional) on the intellectual capital in the pharmaceutical industry companies in Jordan?

\section{Importance of the Study}

The importance of the theoretical study emanates from tackling the literature of an important and recent topic related to the multiple intelligence of the administrative mind and intellectual capital. Its practical importance comes from the need to measure the impact of the multiple intelligence of the administrative mind and the intellectual capital in the pharmaceutical industry companies in Jordan.

\section{Objective of the Study}

The objective of this study is to examine the impact of multiple intelligence of the administrative mind on the intellectual capital in the pharmaceutical industry companies in Jordan.

\section{Model of the Study}

The model of this study is built on the idea that the types of the intellectual capital are predictors of the multiple intelligence for the administrative mind with its dimensions, in the sense that the management of the intellectual capital depends on the level of the multiple intelligence. Al Ali (2003) study on identifying the dimensions of the multiple intelligence and Marr, et al., (2004) study on recognizing the types of intellectual capital were utilized for this model. Figure (1) describes the idea of this model. 
Figure (1)

Model of the Study

\begin{tabular}{|c|c|}
\hline $\begin{array}{l}\text { Multiple Intelligence of the } \\
\text { Administrative Mind }\end{array}$ & Intellectual Capital \\
\hline Business Intelligence & Human Capital \\
\hline Political Intelligence & Process Capital \\
\hline Spiritual Intelligence & Innovation Capital \\
\hline Emotional Intelligence & Customer's Capital \\
\hline
\end{tabular}

\section{Procedural Terminology}

Multiple Intelligence: It expresses the ability of the administrative mind to utilize the business, emotional, spiritual and political intelligences in the pharmaceutical industrial companies for solving the business problems and decision-making. This was measured here by the questionnaire's paragraphs (7-26).

Intellectual Capital: It is the outcome of the system of human capital, process, innovation and customer that are utilized for the sustainability of business value of the pharmaceutical industry companies. This was measured here by the questionnaire's paragraphs (27-44).

\section{Study Hypothesis}

Guided by the inferential question of the study, the following null hypothesis can be formulated as the main hypothesis: There is no impact for the types of multiple intelligence of the administrative mind (business, political, spiritual and emotional) on the intellectual capital in the pharmaceutical industry companies in Jordan at $(\alpha \leq=0.05)$.

\section{Methodology of the Study}

The study adopted the analytical inferential methodology and relied on the testing tools of the model supposition by utilizing the analysis of the multi-linear regression results to ascertain the acceptance or rejection of the null hypothsis.

\section{Population and Sample of the Study}

Thirteen pharmaceutical industry companies were selected as the population of the study, and then the selected sample was composed of (11) companies that have international business. The sampling unit composed of 32 managers and their deputies and assistants in these companies as being the administrative mind which contribute in building the intellectual capital portfolios and their types, in addition to their ability to utilize the multiple intelligence in building, developing and realizing positive results for workers, customers and companies. 
INTERNATIONAL JOURNAL OF ACADEMIC RESEARCH IN BUSINESS AND SOCIAL SCIENCES

Vol. 9, No. 7, July, 2019, E-ISSN: 2222-6990 @ 2019 HRMARS

\section{Reliability of Study Instrument}

The questionnaire paragraphs of the multiple intelligence types and intellectual capital in the pharmaceutical industry companies were drafted by utilizing Al Ali study (2003) and Marr,et al. study (2004). The opinion of competent elite of arbiters was sought to correct the questionnaire paragraphs and their denotations. Likert scale was used to give five options of the responses in line with the actual operations of these companies. Paragraphs (7-26) covered the types of multiple intelligence and paragraphs (27-44) covered components of the intellectual capital.

As for the reliability of the Questionnaire: Values of Cronbach alpha were extracted as stated in the following Table (1):

Table (1)

Cronbach Alpha Coefficient for Determining Liability of the Questionnaire

\begin{tabular}{|l|c|c|c|c|c|}
\hline $\begin{array}{l}\text { Multiple } \\
\text { Intelligence }\end{array}$ & $\begin{array}{l}\text { No. of } \\
\text { Paragraphs }\end{array}$ & $\begin{array}{l}\text { Alpha } \\
\text { Values }\end{array}$ & $\begin{array}{l}\text { Intellectual } \\
\text { Capital }\end{array}$ & $\begin{array}{l}\text { No. of of } \\
\text { Paragraphs }\end{array}$ & $\begin{array}{l}\text { Alpha } \\
\text { Values }\end{array}$ \\
\hline $\begin{array}{l}\text { Business } \\
\text { Intelligence }\end{array}$ & 6 & 0.66 & Human & 3 & 0.69 \\
\hline $\begin{array}{l}\text { Emotional } \\
\text { Intelligence }\end{array}$ & 5 & 0.80 & Operations & 6 & 0.69 \\
\hline $\begin{array}{l}\text { Spiritual } \\
\text { Intelligence }\end{array}$ & 4 & 0.60 & Innovation & 4 & 0.87 \\
\hline $\begin{array}{l}\text { Political } \\
\text { Intelligence }\end{array}$ & 5 & 0.65 & Customer & 4 & 0.67 \\
\hline Total & 20 & 0.85 & Total & 17 & 0.86 \\
\hline $\begin{array}{l}\text { Paragraphs } \\
\text { Total for the } \\
\text { two variables }\end{array}$ & 37 & 0.91 & $\begin{array}{l}\text { Total for the } \\
\text { Instrument }\end{array}$ & 43 & 0.86 \\
\hline
\end{tabular}

Table (1) shows that all Alpha values are greater than 0.60 which is statistically acceptable. This indicates a case of internal consistency between the paragraphs measuring the study two variables in their types and components. Thus, confirms the reliability of the instrument to measure and serve the objectives of the study (Sekaran, Uma, 2003, 203).

\section{Theoretical Framework and Previous literature}

Theoretical Framework: The theoretical framework consists of clarification and theoretical background of the key and sub-variables of the study as follows:

Multiple Intelligence: As organizations face complex business environments, traditional skills are insufficient to ensure success whether at the personal or organizational level. Therefore, these organizations need to develop their competency in terms of multiple intelligence where it is necessary for today's managers to apply and exercise a blend of business, political, spiritual and emotional intelligence in their thinking process, decision-making, motivation, behaviors and various practices. (Sentosa, \& Haji 2013). 
Business Intelligence: As customers constantly change their needs and desires, the organizations become obliged to increase their attention to business intelligence which is known as the organizations ability to obtain and analyze data then get reports to employ such data in exercising their core business. In addition to providing the capability for deep and correct understanding of customers and markets as well as predicting the future trends in providing services, developing products and taking the necessary measures to remain in the forefront (Ranjan, 2009).

Political Intelligence: Organizations cannot be distanced from political events. Most of the practices connected to setting out the appropriate organizational objectives and strategies are not achievable except through negotiations and maneuvering, a matter, which in turn has added to the importance of the political intelligence. This means that realization of the organizational objectives by utilizing appropriate behaviors, strategies and skills for maneuvering and negotiations. Individuals also may build supportive alliances which can influence third party decisions and behaviors as well as build confidence and support at the times of change thus enabling the individual to anticipate reactions of third parties towards his ideas and their possible resistance. (Botticelli et al. 20, 13).

Spiritual Intelligence: Sunita and Anthuvan define spiritual intelligence as the intelligence with which one can access one's deepest meanings, purposes, and highest motivations. It also represents the basic ability of the individual to formulate a set of meanings, values and beliefs he clings to, which have impact on his behavior and decision-making. Writers in this respect refer to spiritual intelligence as the base for the emotional intelligence and that it is the intelligence shown by insightful people like Ghandi and Mandella. They assert that in the world where constant change has become a main feature, leaders need to behave with wisdom and compassion while dealing with moral, environmental and economic issues. They need also to be able to bring about inner peace (equanimity) in which lies the spiritual intelligence as being a basic factor of effective leadership. (Haji et al., 2013, Gage and Smith, 2016 )

Emotional Intelligence: Haji et al., (2013) identify emotional intelligence as the ability to understand our emotions and those of others. They highlight its importance in the collective work through knowing the strengths and weaknesses of ourselves, and our ability to influence others whenever accessible. Emotional intelligence is considered one of the basic determinants and indicators of the individual high performance and success in dealing with others at the personal as well as the organizational levels. The effective leaders do not only have the technical skills, but rather they seek to develop their emotional intelligence, as their participation in multiple functions requires obtaining others' cooperation and support. (Gage and Smith, 2016). 


\section{Intellectual Capital}

Scholars do not agree on how to define intellectual capital, nor do they agree on its components. Accordingly, there is a need to present some related debates and then give greater weight to the definition adopted by the current study.

(Al Ali, 2003:33) study has shown that the intellectual capital is a cumulative of resources, potentials, relationships and networks whether the thinking is resulting from knowledge or notions, or it is emotional and personal such as attitudes, culture or values that enable the organization to form a value or maximize it. Therefore, a number of forms and models of intellectual capital are presented. The most famous model is the one that shows three components for the intellectual capital namely the human, the customer and the structural. Accordingly, the present study gave greater weight to the components of the intellectual capital as follows:

\section{Human Capital}

Human capital includes employee competency, experiences, knowledge, capabilities, enthusiasm, creativity, skills, and personal attributes of the labor of the company or organization and use them to produce economic value (Al Ali and others, 2012:243). Also Al Ali 2003:33 defined the human capital as a stock of total skills, brainpower, and tacit knowledge of the workers.

Processes Capital: The processes capital is considered one of the components of the structural capital. It concentrates on measuring the effectiveness, efficiency, generation and delivery of service to the customer. This can be measured through cost, quality, product and time cycle indicators. For service it possible to add efficiency, customer service, dependency, fast service, response time to complaints according to Customer Service Balanced Scorecard which is one of the measures of the intellectual capital (Ali 2003:43).

Innovation Capital: Peter Drucker indicated that innovation in any field requires talent, ingenuity and knowledge. The innovation capital is measured through two phases; the first is the innovation phase and its indicators in the components of the capital are: human capital with its dimensions (Ideas, skills and concepts of the product); customer's capital with its dimensions (Ideas, product effectiveness, feedback and relationships); and structural capital with its dimensions: organizational knowledge contained in databases, practices, know-how, and culture. This capital can also be measured in a subsequent phase which is the intellectual property: through human capital with the dimensions of (know-how and know-why); customer capital with the dimensions of (trade-mark, reputation, and strategic alliances); and structural capital with its dimensions (patent, trademark, copyright and secret mark) (Al Ali, 2003:64).

Customer's Capital: The customer's capital is known as customer relations and feedback about the product or commodity, customer's comments, experience and his implicit knowledge. The customer definition may be extended to a broader scope to include the distributors, suppliers and any other players who contribute in the value chain (Al Ali, 2003:33). 


\section{Previous Studies}

Miqrash Study (2016) examined the impact of management by (strategic, competitive, and emotional) intelligences on the strategic orientation (orientation to customers, competitor, learning, and innovation) of the Algerian Airlines company. A sample of 174 company employees was selected. The study concluded the following main results:

There is a positive impact of the (strategic and emotional) intelligences on the strategic orientation. There is no impact of the competitive intelligence on the strategic orientation. The study recommended conducting further researches on the multiple intelligences and their impact on other variables.

Farhani study (2016) examined the role of the intellectual capital in its (human, customer, and structural capitals) on realizing a competitive edge with its dimensions (quality, efficiency, innovation and response) in "Ain Touta" cement company - Algeria under knowledge economy. The concluded that: there is an impact of intellectual capital in its human and structural elements on the competitive edge of the company, while there is no impact of the customer capital on realizing the competitive edge.

Twiqar study (2016) examined, the impact of the intellectual capital in its various dimensions on the organizational innovation of the workers. The study targeted the population of (206) male and female workers in Naftal Corporation - Fuel Branch- Skikda. An intentional sample of (62) individuals was selected. The main results of the study were the following: There is a statistical significant impact of the intellectual capital in its (human, structural and customer) dimensions on the organizational innovation in its dimensions (problem solving, decision-making, susceptibility to change, risk-taking and encouragement of innovation) among the workers.

Matt Petersa et al., (2016) study examined the impact of using the business intelligence systems on the possibility of performance measurement to improve the competitive advantage results. The study was conducted in America. Data collected from a sample of 324 executive and general managers from different companies. The study main results indicated that there is a positive and strong impact of the quality of business intelligence systems on the possibilities to measure the performance attributed to the competitive advantage.

\section{What Distinguishes the Present Study from the Previous Ones?}

1. The present study is distinguished from the previous studies in the novelty of its topic and its main and sub-variables, as it came to measure and analyze two important topics in the contemporary management orientations. The two variables are the independent one namely the multiple intelligence and the sub-variables (business, emotional, political and spiritual) and the dependent variable which is the intellectual capital and its sub-variables (human, process, innovation and customer). Whereas the previous studies tackled somewhat similar topics with some variables such as management by multiple intelligence, strategic orientation, business intelligence systems and the intellectual capital and its linkage to the learning organization, innovation, distinction and performance, as well as the emotional intelligence and work teams. 
INTERNATIONAL JOURNAL OF ACADEMIC RESEARCH IN BUSINESS AND SOCIAL SCIENCES

Vol. 9, No. 7, July, 2019, E-ISSN: 2222-6990 @ 2019 HRMARS

2. This study is distinct also by its population. Being conducted on the pharmaceutical industry companies in Jordan, it is unique in its detailed and analytical study for the variables whilst the previous studies tackled different population such as economic, research, banking, airlines and pharmaceutical.

3. The study, up to the knowledge of researchers, is considered the first performed in Jordan in terms of its topic and variables on the pharmaceutical industry companies.

\section{Data Analysis and Results Inferential Statistics}

Testing the Normal Distribution

The normal distribution test was carried out on the dependent variable as a prerequisite for testing the regression. Table (4) shows the results of the normal distribution of the variables:

Table (4)

Normal Distribution of the Independent Variable: Multiple Intelligence in its dimensions, $\mathrm{N}=32$

One-Sample Kolmogorov-Smirnov Test

\begin{tabular}{|ll|r|r|r|r|}
\hline & & BUSINTEL & EMOINTEL & SPINETTL & POINELL \\
\hline $\mathrm{N}$ & & 32 & 32 & 32 & 32 \\
Normal Parameteł's & Mean & 3.96 & 3.96 & 3.77 & 3.90 \\
& Std. Deviation & .520 & .679 & .602 & .493 \\
Most Extreme & Absolute & .184 & .190 & .133 & .115 \\
Differences & Positive & .145 & .132 & .117 & .115 \\
& Negative & -.184 & -.190 & -.133 & -.112 \\
Kolmogorov-Smirnov Z & 1.042 & 1.076 & .753 & .650 \\
Asymp. Sig. (2-tailed) & .228 & .197 & .622 & .791 \\
\hline
\end{tabular}

a. Test distribution is Normal.

b. Calculated from data.

To fulfill the conditions of Pearson Coefficient, the normal distribution test was required based on One-Sample Kolmogorov-Smirnov Test. Table (4) shows ( $z$ ) values for the dimensions of multiple intelligence $(1.042,1.076, .753$, and .650) and all these are below 5 . This is supported by sig. values for all of them $(.228, .197, .622, .791)$, which are greater than the significance level of $(\alpha \leq 0.05)$ thereby confirming the normal distribution of the data. 
INTERNATIONAL JOURNAL OF ACADEMIC RESEARCH IN BUSINESS AND SOCIAL SCIENCES

Table (5)

Normal Distribution Test for the Dependent Variable: Intellectual Capital. Types $\mathbf{N}=\mathbf{3 2}$

One-Sample Kolmogorov-Smirnov Test

\begin{tabular}{|ll|r|r|r|r|}
\hline & & HUCAP & PROCAP & INNCAP & CUSCAP \\
\hline $\mathrm{N}$ & & 32 & 32 & 32 & 32 \\
Normal Parameters ${ }^{\mathrm{a}, \mathrm{b}}$ & Mean & 3.48 & 4.05 & 3.64 & 4.31 \\
& Std. Deviation & .757 & .538 & .764 & .550 \\
Most Extreme & Absolute & .161 & .147 & .115 & .193 \\
Differences & Positive & .112 & .107 & .104 & .106 \\
& Negative & -.161 & -.147 & -.115 & -.193 \\
Kolmogorov-Smirnov Z & & .908 & .831 & .648 & 1.092 \\
Asymp.Sig. (2-tailed) & & .382 & .495 & .795 & .184 \\
\hline
\end{tabular}

a. Test distribution is Normal.

b. Calculated from data.

Table (5) shows $z$ values for the dimensions of intellectual capital $(.908,0.831,0.648$, and 1.092$)$ and they are all less than 0.5 . This is supported by sig values for all of them $(0.382,0.495,0.795,0.184)$ which are greater than the significance level of $(\alpha \leq 0.05)$ thereby confirming the normal distribution of the data.

\section{Testing the Strength of Form}

Person correlation matrix was extracted to test the strength of the association between the two variables; the multiple intelligence and the intellectual capital. It indicated that the $R$ value $=0.809$ and by substitution in the variance inflationary factor (VIF), it indicated the following:

$\mathrm{VIF}=\frac{1}{1-\mathrm{R}^{2}}$

$\mathrm{VIF}=\frac{1}{1-(0.809)^{2}}$

$=2.89 \mathrm{~N} \mathrm{VIF}<5$ and means there is no multicollinearity, thus reflecting the strength of the form.

Multiple Regression Test: In order to know the types of multiple intelligence that have statistical significant impact at $(\alpha \leq 0.05)$, the main hypothesis was tested through the multiple regression using (Enter) method.

Table (6)

Summary of Multiple Regression Analysis

Model Summary

\begin{tabular}{|l|r|r|r|r|}
\hline Model & $\mathrm{R}$ & R Square & $\begin{array}{c}\text { Adjusted } \\
\text { R Square }\end{array}$ & $\begin{array}{c}\text { Std. Error of } \\
\text { the Estimate }\end{array}$ \\
\hline 1 & $.809^{\mathrm{a}}$ & .655 & .604 & .306 \\
\hline
\end{tabular}

a. Predictors: (Constant), POINEШ, BUSINTEL, SPINETTL, EMOINTEL 
INTERNATIONAL JOURNAL OF ACADEMIC RESEARCH IN BUSINESS AND SOCIAL SCIENCES Vol. 9, No. 7, July, 2019, E-ISSN: 2222-6990 @ 2019 HRMARS

Table (6) shows a summary of the multiple regression analysis where the value of the positive coefficient of the multiple intelligence is $R=0.809$. This indicates that there is a strong positive relation between (the business intelligence, spiritual intelligence, emotional and political intelligence) and the intellectual capital in the pharmaceutical industry companies. The correlation coefficient value $0.655=R^{2}$ indicates the capability of the multiple intelligence of the administrative mind (of all types) to predict the intellectual capital in the pharmaceutical industry companies in Jordan.

Table (7)

Analysis of the Multiple Regression Variation

ANOVA

\begin{tabular}{|c|c|c|c|c|c|c|}
\hline \multicolumn{2}{|c|}{ Model } & $\begin{array}{l}\text { Sum of } \\
\text { Squares }\end{array}$ & $\mathrm{df}$ & Mean Square & $F$ & Sig. \\
\hline \multirow[t]{3}{*}{1} & Regression & 4.810 & 4 & \multirow{3}{*}{$\begin{array}{r}1.202 \\
.094\end{array}$} & \multirow[t]{3}{*}{12.820} & \multirow[t]{3}{*}{$.000^{\mathrm{a}}$} \\
\hline & Residual & 2.533 & 27 & & & \\
\hline & Total & 7.342 & 31 & & & \\
\hline
\end{tabular}

a. Predictors: (Constant), POINELL, BUSINTEL, SPINETTL, EMOINTEL

b. Dependent Variable: INTCAP

F value (12.820) in the analysis of the multiple regression in Table (7) indicates that it has a statistical significance at $(\alpha \leq 0.05)$ where sig value in the Table is (0.000). This indicates the validity of the model in interpreting the multiple intelligence impact (emotional, spiritual, business, and innovation) on the intellectual capital in the pharmaceutical industry companies in Jordan.

Consequently, the null hypothesis is rejected, and the alternative hypothesis which states that "There is an impact for the multiple intelligence of the administrative mind (emotional, spiritual, business, innovation) on the intellectual capital in the pharmaceutical industry companies in Jordan at statistical significance $(\alpha \leq 0.05)$ is accepted.

Table (8)

Results of Multiple Regression Analysis

Coefficients $^{\mathrm{a}}$

\begin{tabular}{|c|c|c|c|c|c|c|}
\hline \multirow{2}{*}{\multicolumn{2}{|c|}{ Model }} & \multicolumn{2}{|c|}{$\begin{array}{l}\text { Unstandardized } \\
\text { Coefficients }\end{array}$} & \multirow{2}{*}{$\begin{array}{l}\text { Standardized } \\
\text { Coefficients }\end{array}$} & \multirow[b]{2}{*}{$\mathrm{t}$} & \multirow[b]{2}{*}{ Sig. } \\
\hline & & B & Std. Error & & & \\
\hline \multirow[t]{5}{*}{1} & (Constant) & .591 & .525 & & 1.126 & .270 \\
\hline & BUSINTEL & .438 & .122 & .468 & 3.592 & .001 \\
\hline & EMOINTEL & .118 & .119 & .165 & .997 & .328 \\
\hline & SPINETTL & .422 & .110 & .523 & 3.831 & .001 \\
\hline & POINELL & -.132 & .175 & -.134 & -.755 & .457 \\
\hline
\end{tabular}

a. Dependent Variable: INTCAP 
Analysis of $(t)$ values of the multiple regression variation in Table (8), that is (3.592) for business intelligence and (3.831) for spiritual intelligence with statistical significance at $(\alpha \leq 0.05)$ as the value of the sig which correspond to them is (0.001) in the table and it is less than (0.05).

Accordingly, the prediction regression equation, and through values of a and $\beta$ can be clarified as $Y$ $=a+b 1 \times 1+b 3 \times 3$

intellectual capital $=$ Spiritual intelligence $0.422+$ business intelligence $0.438+0.591$. In other words, in order to increase one unit of intellectual capital by 0.591 an amount of 0.438 of business intelligence +0.422 of spiritual intelligence should be added. This is supported by Beta values the corresponding correlation coefficient values $(0.523,0.468)$ which are positive and direct proportionate values.

Table (8) shows the independent variables namely the (emotional and political) intelligences which did not enter in the regression formula as the statistical values $(0.755, t) 0.997$ and corresponding statistical significance for them $(0.457,0.328)$ which are greater values than the significance level.( $\alpha \leq 0.05)$

\section{Conclusions and Recommendations}

Conclusions: The study concluded the following main results:

1. The is an impact of the multiple intelligence in its two types of administrative mind (business and spiritual) on the intellectual capital in the pharmaceutical industry companies in Jordan at $(\alpha \leq 0.05)$, according to the following prediction formula: Intellectual capital $=3.952+$ business intelligence $0.0591+$ spiritual intelligence 3.831 . This may be interpreted by the fact that in order to increase one unit of intellectual capital 0.591, an increase of 3.592 units of business intelligence $+3,831$ units of spiritual intelligence has to be increased.

2. There is no impact of the multiple intelligence of administrative mind in its two types (emotional and political) intelligence on the intellectual capital in the pharmaceutical industry companies in Jordan at $(\alpha \leq 0.05)$. This conclusion has disagreed with Miqrash study (2016) in Algeria that found an impact associated with the emotional intelligence on the strategic approach.

\section{Recommendations}

Based on the Study conclusions, the study recommends the following:

1. Enhancing the utilization of multiple intelligence of the administrative mind in the pharmaceutical industry companies in Jordan by focusing on the various types of intelligence that enable companies to achieve a distinguished competitive edge locally, regionally and internationally.

2. Continuing to enhance the two types of intellectual capital (customer and operation) due to their value in achieving customers' satisfaction and loyalty to the medicine, its good 
reputation and competitive edge as well as in reaching regional and international distribution outlets.

3. Enhancing the focus on business intelligence and spiritual intelligence due to their positive and direct impact on the intellectual capital of the pharmaceutical industry companies in Jordan.

\section{References in Arabic Language}

Tawfiq, A. (2002). Management Intelligently, Better Results, Less Resources, Publications of the Center of Management Professional Expertise, (BEMIC) 40, Cairo, Egypt.

Thomas P. (1999). Search for Excellence, Lessons Learnt from Administrative Experience of the Best American Companies, Translated by Dr. Sayyid Mutwalli, Jareer Library- Saudi Arabic .

Twiqer, R. (2016). Impact of Intellectual capital on Organizational Innovation in the Economic Corporation, M. A, Thesis, Mohammad Khaidhar University, Baskara, Algeria..

Gulman D., Boyatzris R., Maliki A. (2004). New Leaders, Transfer of Management Leadership Art to Results Science, Translated by Othman Mathloothi and Basheer Sa'eed, Dar al MareekhRiyadh, Saudi.

Al-Ali A., Qandeelgi, A., Alomari G., (2012). Introduction to Knowledge Management, $3^{\text {rd }}$ edition, Dar Al-Maseerah for Publication, Distribution \& Printing, Amman- Jordan

Farhani, L. (2016). Role of Intellectual Capital in the Realization of Competitive edge for the Economic Corporations under Knowledge economy. A case study of "Ain Touta" Cement Company, Ph.D. Dissertation, Mohammad Khaidhar University,Baskara, Algeria.

Mohammad, A. (2014). Intellectual Capital and its Impact on the Realization of Comprehensive Quality and Institutional Excellence (Field Study: Universal Charitable Optical InstitutionMecca Technology College Fore Ophthalmic Medicine

Miqrash, F. (2016). Impact of Administrative Intelligences on the Strategic Orientation of the Organization- case study of Algeria Airways Company, Ph.D. Dissertation, Mohammad Khaidher University,Baskara, Algeria.

\section{References in English Language}

Al-Ali, N. (2003). Comprehensive intellectual capital management: Step-by-step. John Wiley \& Sons. Bambang, B. S., \& Saputra, W. S. The Intelligence, Emotional, Spiritual Quotients and Quality of Managers. Global Journal of Management and Business Research Administration and Management, 2(7), 1-17.

Botticelli, C., Kanter, J., Wasserman, A., \& Murphy, S. (2013). Political Intelligence Firms - Insider Trading and Enforcement Shifts from Wall Street to K Street, The Investment Lawyer Journal, 20(12), PP. 1, 8-15

Boyce, S. Y. (2007). Using intellectual capital and organizational capability to enhance strategic implementation for pharmaceutical firms. Journal of Business and Public Affairs, 1(1), 1-3.

Gage, T., \& Smith, C. (2016). Leadership intelligence: Unlocking the potential for school leadership effectiveness. South African Journal of Education, 36(4), 1-9.

Jurczak, J. (2008). Intellectual capital measurement methods. Economics and organization of enterprise, $1(1), 37-45$. 
Marr, B., Schiuma, G., \& Neely, A. (2004). Intellectual capital-defining key performance indicators for organizational knowledge assets. Business Process Management Journal, 10(5), 551-569.

Peters, M. D., Wieder, B., Sutton, S. G., \& Wakefield, J. (2016). Business intelligence systems use in performance measurement capabilities: Implications for enhanced competitive advantage. International Journal of Accounting Information Systems, 21, 1-17.

Sangari, M. S., \& Razmi, J. (2015). Business intelligence competence, agile capabilities, and agile performance in supply chain: An empirical study. The International Journal of Logistics Management, 26(2), 356-380.

Sekaran, U., \& Bougie, R. (2016). Research methods for business: A skill building approach. John Wiley \& Sons.

Senge, P. M. (1997). The fifth discipline. Measuring Business Excellence, 1(3), 46-51.

Sunita, R., \& Anthuvan, V. L. (2015). Spiritual Intelligence and Entrepreneurial Success in Family Business: An Enquiry. IOSR Journal of Business and Management. 17(6). PP 13-20.

Vandergriff, L. J. (2008). Welcome to the Intelligence Age: an examination of intelligence as a complex venture emergent behavior. Vine, 38(4), 432-444. 